\title{
RESEARCH ARTICLE \\ The body and the deed. Places of rape in Swedish court narratives
}

\author{
Ulrika Andersson \\ Professor in Criminal Law, Faculty of Law, Lund University, Sweden.
}

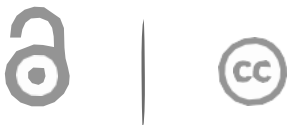

Open Access

Citation: Andersson, U., The body and the deed. Places of rape in Swedish court narratives. Gender and Women's Studies. 2021; 4(1):2.

Received: August 07, 2020

Accepted: December 29, 2020

Published: January 12, 2021

Copyright: (c) 2021 Andersson, U. This is an open access article distributed under the terms of the Creative Commons Attribution License, which permits unrestricted use, distribution, and reproduction in any medium, provided the original author and source are credited.

\section{Corresponding author:}

Ulrika Andersson, Professor in Criminal Law, Faculty of Law, Lund University, Sweden;

E-mail: ulrika.andersson@jur.lu.se

\begin{abstract}
A fundamental starting point for this article is that place in a broad sense is a crucial, yet forgotten, dimension in the legal analysis of rape. Therefore, in this study I ask what role place has in the adjudication of rape; in the interpretation of rape law as well as in the evaluation of evidence. I analyze three Swedish rape cases, two from the Supreme Court, marking out the sexual act of rape, and one case from an appellate court, applying this rule. The latter is closely related to the Swedish \#metoo movement and extremely high-profiled. I take a closer look at how the act of rape is linked to place in these judgements. Concretely, I study the narration and classification of the crimes, including the legal labelling and the positioning and portrayal of the complainant and the defendant. My main conclusion is that place is quite absent in the courts' legal narratives of rape. In my view, notwithstanding obvious place-related events. Apart from stressing the place of the body, in the first case, place was absent in the legal narratives in all instances. The court did not touch upon the question of whether the complainant should be able to feel safe in her own home and not have to fear violence and abuse. Nor did it touch upon similar aspects in the third case where the occupational and the public character of the place and shame, according to the victim's own story, hindered her from reacting loudly. In the second case, the appellate court invoked place by implicitly stressing home and belonging when noting that the young man was far from home, thus being particularly vulnerable. Later the Supreme Court declared that sexual vulnerability should not be related to place at all and decided not to label the event as rape.
\end{abstract}

\section{Keywords}

Rape, Swedish court narratives, \#metoo

\section{Introduction}

During the \#metoo movement in the autumn of 2017, stories about sexual assault, including rape, garnered much attention worldwide. It might seem as if all of these stories came from nowhere. In fact, during the last decades countless rape cases have been highlighted and debated in media all over the world. These discussions in the media and among the general public have led to scrutiny and a critical review of the applicable law and the legal system. For example, the handling of rape in Swedish criminal law has been under critique for the last two decades, with debate on the topic tracing back to the 1970s (Wendt Höjer, 2002 and SOU, 1976:9). This critique concerns, among other things, the definition of rape and treatment of victims during the criminal legal process, and has come from multiple directions: the media, legal scholarship, legal practitioners, feminist academics, and the general public (Leijonhufvud, 2015; Fatta, 2018). The media play a major role in shaping this contemporary debate on rape (Andersson \& Edgren, 2018; cf Martin Alcoff, 2018: 23). In Sweden, the media have frequently been instrumental in naming and framing cases of rape based on where the assault took place, thus linking the deed to place in a broader sense (Nilsson, 2018). Besides the media, Swedish courts also participate in promoting a connection between rape and place (Andersson \& Edgren, 2018). Contemporary legal discourses, too, relate rape to place: for example, through the 
use of such terms as 'date rape', 'rape on campus', 'rape on the internet' and 'rape in wartime' (e.g. Tuerkheimer, 2013, Marvel, 2016, McGlynn, 2008). There is, indeed, scholarly research that focuses on and explores the issue of where rape takes place (Bitsch \& Klemetsen, 2017, Bumiller, 2008, Edgren, 2019, Nilsson, 2019, Ceccato, Li \& Haining, 2019). But there is still a need for more explicit inquiry into how space, including place, is related to rape in law and legal practice, one that simultaneously deals with the legal analysis of rape. This need is confirmed indirectly by legal geographers who suggest that law is 'antigeographic' and call for the study of 'law and non-geography' (Bennett \& Layard 2015). Also legal scholars have called for the need of a spatial awareness in law and legal scholarship (eg. Philippopoulos-Mihalopoulos, 2018, 2015, 2010).

\section{Aim \& Material}

In this article my aim is to make visible that place ought to play a crucial role in the adjudication of rape; in the interpretation of the law as well as in the evaluation of evidence. I have chosen the term place to emphasize the materiality of spaces and to remind us that law, in spite of its textual and discursive character ultimatey deals with real people who live and interact with other real people in real places (cf Johnston \& Lunghurst, 2010, 16). With Johnston and Longhurst space here refers to something that is '... complex, changeable, discursively produced, and imbued with power relations.' (Johnston \& Longhurst, 2010, 16). They also stress that '...space, place and sex are inextricably linked.' (Johnston and Longhurst, 2010, 2).

A fundamental starting point for this article is thus that place in a broad sense is a crucial, yet forgotten, dimension in the legal analysis of rape. This is particularly true in the interpretation of complainant vulnerability (cf Andersson \& Edgren, 2018), which in turn may be connected to defendant culpability (Andersson, 2018). I argue that place is highly relevant in an analysis of rape and should be taken into account both in legislation and in legal praxis. All legal issues are ultimately related to an individual case or question. Place is a suitable tool to use to apply theoretical issues in individual cases, particularly as it is a concept which has both theoretical and concrete bearings (cf Longhurst, 2010). Thus place-related considerations could be used to transcend structural or overall theoretical inclusion in legal analyses.

Below I analyze three Swedish rape cases, two from the Supreme Court and one case from an appellate court. The latter is closely related to the Swedish \#metoo movement and extremely high-profiled. I take a closer look at how the act of rape is linked to place in legal practice, by unmasking legal narratives of rape in which different subject positions for complainants and defendants may be found. Specifically, I look at whether and how place is narratively connected to sexual vulnerability and agency in these Swedish court cases.

The cases I study are two Swedish Supreme Court cases that were decided in 2008 and one appellate court case, related to the Swedish \#metoo movement. The first two cases both involved defining the kind of 'sexual act' that constitutes rape under Swedish criminal law. I have selected these cases since they were the first precedential cases on this issue after the section on rape in the Swedish Penal Code was amended in 2005, and this part of the law has not changed substantially since then. The amendment was the result of intense critique and debate regarding the legal treatment of rape, but the change in the language defining the sexual acts that may constitute rape was minor and related to a change in 1998 (Andersson \& Edgren, 2018). Overall, however, the amendment represented the first major change to the Swedish rape law for two decades. Before these changes in 1998 and 2005, the definition of the sexual activities that constituted rape had only been amended once - in 1984, when new language made the definition gender neutral - since the modern penal code was introduced in 1965.

Many contemporary rape cases from the Swedish Supreme Court deal with questions of evidence (cf Andersson, 2004). As noted above, I have previously analyzed such cases and how courts participate in framing rape in relation to place (Andersson \& Edgren, 2018). In the first two cases I study here, the courts decided upon a substantive matter of criminal law, namely the meaning of the term 'sexual act' which constitutes one of the elements of the Swedish legal definition of rape (NJA, 2008 s. 482 I \& II). Although my analysis is limited to three cases, it is in itself important since the first two cases deal with a substantive matter and the last case deals with a similar sexual act as the first Supreme Court case. Another 
reason why I have chosen them is that it is of great interest to explore how the 'sexual act' of rape is related to place. The first two cases are also suitable for analysis since they were decided together, and were similar in several key respects: both concerned young people who were assaulted while they were sleeping. There were also differences between them, however, in terms of gender, body and place. It is also worth mentioning that the outcomes in these two cases were upheld in a Supreme Court case from 2013 (NJA, 2013 s. 548).

These cases did not provoke much media attention, but have been taken up by some Swedish legal scholars. Petter Asp's analysis very much follows the Supreme Court line; Linnéa Wegerstad has argued that he excludes gender theoretical aspects (Asp, 2008; Wegerstad, 2012).

The last case, concerning a defendant from the Swedish tv-industy, was reported to the police after the complainant had been interviewed for an article in relation to the \#metoo movement (JDC1, 9). It deals with matters of evidence but concerns a sexual act which is similar to the one in the first Supreme Court case. Therefore I have chosen this case since it is important to contrast to the cases from 2008, particularly as it is a current case which has been highly debated and criticized in relation to the \#metoo movement.

The judgments from the cases are my primary material. Judgments are vital to the treatment of rape in criminal law. They show what information about an event is considered legally relevant. In particular, I analyze the relevance of place in relation to sexual vulnerability and agency in these legal narratives, by looking at how the information about these events is made 'legal'. What is considered legally relevant and what is not? My intent is to make visible what information, according to courts, is considered legal and non-legal in relation to the sexual aspect of rape, seen through the lens of gender, place and vulnerability (Smart, 1998 and Mardorossian, 2014).

Below, I elaborate on the workings of Swedish rape law, but first I will address my theoretical points of departure.

\section{Theoretical and Methodological Approach}

In a wide sense law and legal practice is related to place at all times, in the way that an individual case is always occurring at a certain place, be it 'real' or virtual. Procedurally, the place where a crime is committed is fundamental for the whole trial and sets the frames for the criminal procedure and must be specified and bounded, together with the time of the event. In criminal law there are also certain rules related to certain places, for instance it is not allowed to drive in certain streets. Some crimes, eg. offensive photography in the Swedish penal code, only covers certain kind of photographing in certain private places (Swedish Penal Code, Ch 4 sect. 6a).

On the other hand the relevance of place in law, legal theory and practice has not been focused to a great extent, at least not in mainstream legal scholarship. As already mentioned, law has also been described as 'anti-geographic'. However in recent decades, some scholars have been arguing for the relevance of a spatial awareness in law (eg. Braverman et al., 2014). These researchers are interested in the mutual construction between law and geography and the field can be described

'as a stream of scholarship that makes the interconnections between law and spatiality, and especially their reciprocal construction into core objects of inquiry. Legal geographers contend that in the world of lived social relations and experience, aspects of the social that are analytically identified as either legal or spatial are conjoined and co-constituted.' (Braverman et al., 2014: 1)

Further, some scholars seek to promote and develop the field of feminist legal geography and claims it has 'a central role to play in this endeavor in revealing and elaborating on the law-space nexus from a feminist perspective...' and that there is a need 'for the mantle to be shared by feminist geographers and feminist legal scholars through greater exchange and partnership.' (Cuomo and Brickell, 2019). Braverman et al. claims that 'most [legal scholars] continue to explore space, place, and landscape without the full benefit of the array of resources developed by geographers and others' (Braverman.et al., 2014: 8). This article is an attempt to remedy this situation and use research developed by geographers, particularly feminist (legal) geographers.

In relation to place and in the wake of groundbreaking books by Henri Lefevbre on place and space (1991), Benedict Anderson on imagined communities (1991) and Nira Yuval Davis 
on gender and nation (1993), feminist geographers have written extensively on how home, the public space, the community and the nation are constituted by gender, sexuality, nationality, race, ability and so forth, touching on many different themes (e.g. Massey 1994; Johnston \& Valentine, 1995; Valentine, 1992; Pain 1997; Blunt, 2002; Molina, 2007; Johnston \& Longhurst, 2010). Writings on the meaning of "home", for instance, have touched on a multitude of angles (Mallett, 2004). The ambivalence disclosed in the concept of home - which is not only where we dwell, cook, eat and learn appropriate social roles, but which is also invested with meanings such as belonging, intimacy, fear, and danger related to violence, to gender and family, to sexuality, to homelessness (e.g. Valentine, 1992, 1995; Ahmed, 2000; Blunt \& Warley, 2004. Johnston \& Longhurst, 2010; Thörn, 2004; Edgren, 2011, Tyner, 2012) - is useful to have in mind. What interests me is certain meanings relating to belonging and not belonging; being in the right place or out of place (Moran and Skeggs 2004). Also to explore the body as a space and the body in space in relation to rape law and practice seems utterly important, as does the courts' treatment of the relationship beween bodies and places (cf. Johnston and Longurst, 2010, 21ff, Jeffrey, 2020). Geographers argue that bodies are '...places where discourses and power relations are mapped, embodied and resisted...' (Bonner-Thompson \& Hopkins, 2017).

In this article I would like to highlight the relevance of place in the legal narratives on sexual vulnerability (and agency) and how the lack of focus on place in the legal argumentation prevents aspects of power, here in relation to gender, sexuality and age, from being taken into account. Narratives where sexual agency is related to vulnerability and connected to place are not unusual in rape cases (Andersson \& Edgren, 2018). For example, if a rape has been committed in a place unknown to the complainant, $s /$ he may be regarded as particularly vulnerable (Andersson \& Edgren, 2018, case NJA, 1997 s. 538). On the other hand, if a rape takes place after the victim invites the perpetrator home, courts are more likely to assign the complainant agency (Andersson \& Edgren, 2018, case NJA, 2004 s. 231). In the cases studied in this article, such explicit narratives on place are less visible: particulary in the reasoning of the Supreme Court, which, as already noted, establishes the interpretation of law. However, as I will show, place is made relevant implicitly.

Like other areas of law, rape law rests on the liberal assumption of the individual's autonomy and agency, meaning that a legal subject is considered free and competent to make rational choices. This notion leaves the individual bounded and separate from various contexts. Thus many aspects surrounding the individual are normally not taken into account in law and legal practice, at least not deliberately. Several scholars have opposed this view, arguing that the assumption of liberal autonomy conceals a structural power that can leave subjects vulnerable (eg, Grear, 2010, Niemi, 2010, Naffine, 2004 and Lacey, 1997). In analyzing legal narratives of rape, my aim is to focus on vulnerability in relation to place, gender and body. As Linda Martin Alcoff puts it, all narratives are plausible within certain frames that set out who can be victimized, who can be accused, and who is intelligible within certain discursive formations (Martin Alcoff, 2018, 23). Discursive formations on place, gender and body are my specific objects of study in this article.

I ask in what way rape law and legal practice is linked to place, gender and body. In relation to how vulnerability and agency are expressed in court narratives, rape law, as just noted, rests on the assumption of a liberal subject with individual autonomy. In any individual case, this assumption may conceal structural power that leaves the subject vulnerable (see eg. Grear, 2010; Niemi, 2010; Naffine, 2004; Lacey, 1997). Taking issue with the liberal subject, Martha Fineman has argued that vulnerability as a human condition should instead be seen as the starting point for the legal subject (Fineman 2008, 2010, 2017). This line of thought sees vulnerability as both embodied (in individual factors such as illness, harm or experience of rape) and embedded (in the organization of societal institutions and relationships). Using this approach, I am able to argue for a notion of vulnerability and agency that is connected to place. For instance, individual autonomy and trauma may be related to structural factors such as patriarchal notions of female sexuality, and these in turn may manifest differently in connection to different places (Andersson \& Edgren 2018). Considering the relevance of place in the interpretations would make it possible to legally interpret sexual offences in relation to aspects of power (cf Andersson \& Wegerstad, 2016, McGlynn, 2008, Smart, 1998).

I would like to argue that place is key to the analysis of rape, in terms of the legal issue as well as in terms of the issue of fact, which are intertwined. The legal analysis thus depends 
on place, particularly, which I will show, as in where the deed took place, but also in terms of the place of the body, the complainant's body as well as the defendant's. This in turn affects the legal interpretation as well as the evaluation of evidence, which as just said are intertwined.

\section{Swedish Rape Law}

In the cases studied, the applicable Swedish law of sexual offences were construed as sexual acts associated with force or exploitation (Andersson 2001, Andersson 2004). The crime of rape involves acts that are labelled in the same sexual terms - for example, 'sexual intercourse' - as those used to describe mutual sexual acts. Thus, the language of rape legislation and practice is blurred and in a way hijacked by the language of a discourse of erotic sexuality (cf Wegerstad, 2012; Wegerstad, 2015).

Further, all sexual acts are gauged against intercourse, which in practice mostly means some kind of penetration. Essentially, this is based on a view of heterosexuality that has prevailed since the nineteenth century, adhered to by men and women and linked to the notion of difference between male and female sexuality (Bergenheim 2005, 73 and Ekström $2001,153)$. Sweden only very recently introduced non-voluntariness as a basis for the definition of rape (prop 2017/18: 177). Until 1 July 2018, the decisive criterion in the provisions on rape was force, whereas, for example, English law focuses on the victim's will, or lack of consent (Andersson, 2001 and Temkin, 2002). Thus, the elements of force or exploitation have set the legal boundaries of these offences. Despite this focus on force and exploitation, in practice consent and will have dominated (Andersson, 2004).

As mentioned, however, the definition of the sexual act of rape has not been changed to any great extent since 1984. At that time, rape law was made gender neutral by allowing that rape could be a sexual activity comparable to heterosexual intercourse - the latter being the earlier prerequisite (Prop. 1983/84: 105, 76). Primarily this change referred to acts of oral or anal penetration. A minor expansion of this notion was introduced in the amendment from 2005. The precise meaning of a 'sexual act comparable to heterosexual intercourse' was elaborated by the Supreme Court in the first two cases I analyze below. It was also tried in the last case. I will begin by introducing the case material and then give an account of the court's narratives, followed by an interpretation of the cases through the lens of gender, place and body.

\section{The Cases}

As already mentioned, in contrast to many other rape cases from the Swedish Supreme Court, the first two cases deal with substantive issues of criminal law. These cases were partially decided together and even referred to by the same number in the law reports, Nytt Juridiskt arkiv, NJA 2008 s. 482 I and II. My main material consists of the judgments in both cases, as presented in the reports. The reports cover the judgments from three judicial instances in each case. Each judgment is structured around the decision itself and the court's grounds for that decision. It is in these formal justifications that the stories from the parties to the case are rehearsed, and as part of the assessment of the evidence, the information from these statements is evaluated for its probative value. The court mediates the stories from the defendants, the complainants, the witnesses and the evidence of various types; using these stories, the court establishes the background to the case. In the process, the court arranges events by ordering scenes in temporal and spatial sequences, making truth claims (Andersson \& Edgren, 2018).

The first two cases at hand dealt with the same legal question: the meaning of a 'sexual act comparable to heterosexual intercourse'. Some other circumstances were also similar: both complainants were young and both were assaulted when asleep. In the first case the defendant and complainant were about the same age, but in the second case the defendant was more than 35 years older than the complainant, and the complainant's employer. One significant difference between the two cases was that the first complainant was a young woman, while the second was a young man. It should be noted neither the Supreme Court nor subsequent legal scholarship observed this fact particularly (Asp, 2008, cf Wegerstad, 2012). Here, I will deal with the cases in the same order as the Court. I focus on the language and the structure of the court narratives, the stories told and the way the courts put forward their legal reasoning. 
In the first case the defendant was accused of rape and sexual assault, alternatively. According to the prosecution, he had inserted his fingers into the complainant's vagina while she was sleeping. The court presents a story about how the complainant and her friends were drinking wine in her flat. During the course of the evening another six or seven people, including the defendant, came to the flat, and later they all went in separate cars to a city nearby. Some went to a pub and some, including the complainant, drove around in one of the cars for a couple of hours. At the pub the defendant met a friend who was very drunk. They both went back to the complainant's flat to wait for half an hour before the complainant arrived. The way the court reproduces the parties' stories is, to a great extent, affected by the questions asked by the prosecutor and the defence. In the judgment, however, these questions are not visible. The complainant's story is about what happened during the assault, her reaction, how she was dressed, her earlier experience of sexual assault, the fact that she had spent a short period of time in psychiatric care, her studies and her participation in a television show about sexual assault against women. On the night of her assault, the complainant woke up with a sense of unease and feeling pain in her vagina: 'at first she did not realize what was happening, but later understood someone was lying next to her and had inserted several fingers into her vagina' (484). The defendant's story is about what did not happen, according to him: why he left the apartment in the middle of the night, his activities the next morning and why he texted an apology to the complainant, in spite of not having done anything.

The district court found it proven beyond a reasonable doubt that the defendant inserted his fingers in the complainant's vagina (487). Neither the district court nor the appellate court (487-494) found this act comparable to intercourse, and the defendant was convicted of the less serious crime of 'sexual coercion', rather than 'rape'. In the Supreme Court (496-498), the argumentation about the meaning of the term 'sexual act' led to the opposite outcome, and the defendant was convicted of rape. The core of the argumentation was about penetration: The complainant was 'subjected to a penetration of the vagina, not being insignificant, which has caused a certain pain' (497). The court then reasoned about the violation as follows: '[t]he violation of being subjected to such an act must be considered similar to the violation of being subjected to forcible intercourse' (498).

Obviously the narrative used in interpreting this prerequisite is phallocentric, in that the court clearly viewed penetration of the vagina by a penis to be the most serious form of sexual violation (Wegerstad, 2015, Boyle, 2018). Further, this implies that rape is a matter of violation of a certain place of the female body - the vagina - by a certain place of the male body - the penis. This situation is also the one the Supreme Court ruled to be rape in this precedential case, and it is also confirmed in the third case below, however the court didn't find that act proven. So, the place of the complainant's body, the woman's vagina, is quite central and visible in the court's narratives and legal reasoning. The fact that the defendant's fingers are inside the complainant's body, her vagina, is made relevant and completely crucial to the outcome of the case, which hinges on whether the sexual act that transpired can be considered comparable to intercourse. The place of the complainant's as well as the defendant's body is, I would say, made relevant implicitly. I argue this is due to a lack of awareness of the relevance of place in relation to rape. It is quite clear that the legal assessments given by the courts in their judgments are seemingly separated from placerelated aspects. Through this demarcation in the courts' reasonings, place, and in turn the relation of sexuality to power, gender and age among others, become irrelevant in the legal interpretations. Conversely, if the question of place were overtly taken into account, aspects that I believe should be included in the legal reasoning and events connected to different places, with various connotations could be made visible: a party at home or in relation to an occupational activity, where you should have the right to be safe or a work trip with a stay overnight in a hotel, far away from home where you might be more vulnerable.

In the second case, all of the judicial instances issued very brief judgments. The prosecution accused the defendant of rape for having 'masturbated the complainant' (498499). In other words, the accusation is very implicit; above all it employs a vocabulary normally used for consensual sexual behavior. This is quite remarkable from at least two perspectives: first, in a strictly legal sense, since the specification of the deed is a fundamental procedural requirement, and using the word 'masturbate' is not an explicit description of what actually happened; and second from a critical feminist perspective, as the consensual language effectively conceals aspects of power and abuse (cf Boyle, 2018). 
Some portions of the grounds for decision are classified and not part of the judgment, so the narratives are very short but the appellate court, however, reveals that 'the complainant was far from home in an intoxicated state, into which he - in spite of his youth - was aided by [the defendant], and the complainant should have been able to feel safe' (500). Further, the complainant was an employee of the defendant (undergoing a trial period) and the two were on a business trip and staying overnight in a hotel when the assault took place. The district and appellate court both found the defendant guilty of rape; accordingly, both courts assessed the sexual act as being comparable to intercourse. The narratives from these courts contextualized the sexual act and related the event to the complainant's age (young), the place of his assault ('far from home'), and his position as an employee of the defendant (500-501). The Court of Appeal, especially, took power relations implicitly into account in its assessment, claiming that the defendant 'must be considered as responsible for the complainant' during the trip and that 'the complainant should have been able to feel safe in [the defendant's] company' (500). The Supreme Court, however, in a remarkably brief opinion, simply cited preparatory works to the current rape law and declared that it found no reason to depart from their guidance:

If a perpetrator masturbates another person, this is not, in most cases, to be considered abuse of such a nature as to constitute a violation comparable to forced intercourse [...] No reasons to make any different assessment of the act at issue in this case have emerged (502).

Based on this reasoning, the Supreme Court overturned the lower court ruling and convicted the defendant of the less serious crime sexual coercion. The aspects of power that the Court of Appeal took into account in assessing the sexual act - the complainant's age and the defendant's responsibility for the defendant in his role as an employer - were only assessed by the Supreme Court in relation to the defendant's recklessness and whether the crime could be viewed as gross, which the court found it could not (502).

In this case case, the perpetrator's language prevailed (Niemi-Kiesiläinen, Honkatukia \& Ruuskanen, 2007, Ehrlich, 2001, Brooks, 2002) and the prosecutor claimed that 'the defendant masturbated the complainant' (Boyle, 2018, Estrich, 1987). Here, rather than abuse, the presumption is almost the reverse: a mutual sexual encounter. The underlying message is that rape is a crime committed against women and female sexuality, through penetration, which appears as the ultimate violation. This is an excellent illustration of the heteronormative framing of vulnerability and sexuality in relation to rape (Estrich 1987, cf Javaid, 2018). In contrast, in the second case, the male body is obscured, and so is potential male violation, which instead is framed as masturbation (cf Javaid, 2018). And place is not made relevant. The court does not remark on the complainant's sexual vulnerability and constrained agency in a hotel room with an employer many years older (Grear, 2010, Andersson \& Edgren, 2018).

In the third case, which took place several years before the \#metoo movement but was reported and tried in court in close relation to it, the defendant was accused of rape. According to the prosecution, he had inserted his fingers into the complainant's vagina while holding her, forcing her to stay in a tub where they both were sitting together with some other persons, as part of a work related kick-off event. The sexual act thus resembles the one in the first case above, where it was considered equivalent to sexual intercourse by the Supreme Court. The circumstances in this case where however somewhat different. As in the second case above the current event occurred during an occupational activity outside work. The court presents a story about the working relations between the involved parties, and frames the evening of the event as a kickoff for the editorial office of a famous Swedish TVshow. The kickoff took place in a country house that belonged to the defendant and the house was situated on an island. The defendant was at the time working as an anchor man of this TV-show. He ran his own business, which was hired by a Swedish commercial channel. The complainant was working as an assistant in the editorial office of the same TVshow but was hired by another television company. The people at the kickoff are described as 'party attendees' (4). In the evening after dinner, where alcohol was served, some people were having a sauna or were bathing in a hot tub, which was placed on the bridge close to the sauna and filled with water from the ocean, heated with firewood. It so happened during the evening that the defendant and the complainant were sitting in the tub at the same time, with a number of other persons. After a certain period of time the complainant left the tub and some more time thereafter she left the party by boat. Some other persons were in the same 
boat, which was driven by the producer of the TV-show. The complainant's story in this case is about what happened during the assault, the defendant inserted two or three fingers quite far into her vagina, perhaps ten centimeters, her reaction to this, how many persons that were in the tub at the time of the event, where the defendant was sitting, how drunk each of the persons were and whom she was telling about the assault after it had happened and when (JCA, 4-9). The court also focuses on the issue of the time of the reporting of the crime and what the defendant was telling her the day after, various meeting with bosses at the tvcompany and what made her go through with a report to the police (JCA, 9). The defendant's story is about what did not happen, as in the first case above. He did not insert his fingers into the complainant's vagina but might have put his hand on her buttocks, above the water surface, partly to prevent her from burning on the warm heaters and partly because he thought it was funny. He should not have done it and did not mean anything.

In spite of the presence of numerous oral testimonies, supporting the complainant's story, the court reached the conclusion that because of the time that had passed since the event took place and the possibility for everyone to talk to each other, reading about it in media and on facebook, thus affecting each other's stories, it was not proven beyond reasonable doubt that the defendant had committed the crime he was accused of.

The defendant's fingers are indeed inside the complainant's vagina according to the story presented by her and this is also trusted by the court initially. However, in my view, it seems the absence of the 'right' place of the defendant's body, his penis, together with the 'public' place of the event, the tub in the midst of all people, affected the court's evaluation of the complainant's story. Here it seems the court is expecting that someone ought to have seen something would the complainant's story be true, and why would the defendant risk to be caught in the act? These place-related implicit conclusions altogether hindered the court from reaching beyond reasonable doubt in this case.

As in the second case above this case was taking place on an occupational activity. Here too the complaint's sexual vulnerability is obviously marked by the fact that the defendant is older, famous and superior but also that the event is taking place among other people and above all of his place, his country house, situated on an island, which might have been difficult to leave (Mallett, 2004, Andersson \& Edgren, 2018).

\section{Gender, Place and Body - Conclusion}

The phallocentric place of the male body, heteronormative notions of sexuality, and in turn the stereotyped notion of how female sexuality is violated with its relation to the place of the female body, allow the situation in the first case, which involves penetration with a penis, to count as rape. The second case on the other hand, where violation of the penis is described in mitigating language as masturbation, or the third, lacking involvement with the defendant's penis at a place of sexual vulnerability, are not judged to be rape. Apart from stressing the place of the body, in the first case, place is absent in the legal narratives. As I have shown, the court did not touch upon the question of whether the complainant should be able to feel safe in her own home and not have to fear violence and abuse (Mallett, 2004). If these aspects had been included in the assessment, the severity of the crime might have been judged greater and in turn affected the sentence. Even more importantly in my view, including place-related aspects might affect the perception of violence in intimate relations at a societal level.

Nor did the court touch upon similar aspects in the third case where occupational relations, shame and the public character of the abuse, according to the complainant's own story, hindered her from reacting loudly (Niemi, 2010 Andersson \& Edgren, 2018). In this case, these place-related aspects would most likely have affected the court's evaluation of the complainant's story should they have been taken into account, and it might have reached the conclusion that the prosecution was proven beyond reasonable doubt's. Further, due to the unawareness of the relevance of place, there is no discussion of which place of the defendant's body is used to violate the complainant.

In the second case, the appellate court invoked place by implicitly stressing home and belonging when noting that the young man was far from home. An underlying assumption in this narrative is that the complainant was particularly vulnerable since he was far away from home. On the other hand, the place of his body was not at all scrutinized in the legal reasoning. Later, the Supreme Court declared that sexual vulnerability should not be related 
to place at all and assessed this situation as the less serious crime that is not labelling it as rape.

To conclude, the place of the deed in combination with the place of the body are crucial in the courts' narration and ought to be part of the legal analysis of rape as well, to promote just outcomes in terms of the evaluation of the evidence, the interpretation of rape law and the assessment of the penalty (cf. Cuomo and Brickell, 2019, Jeffrey, 2020). Here the disregard of these aspects rendered the courts unable to consider neither the second nor the third situation as rape. In the second case: the exclusion of the relevance of the place of the deed, together with the violation of the 'wrong' place of the body, opened up for a framing of the abuse as masturbation. In the third: lack of the phallocentric place of the defendant's body in the deed, together with the 'public' character of the place of the deed, in my view crucially affected the evaluation of the evidence as not reaching beyond reasonable doubt.

\section{Funding \& Acknowledgement}

This article is part of the project "The \#metoo momentum and its aftermath: digital justice seeking and societal and legal responses", funded by Marianne and Marcus Wallenberg foundation, MMW 2018.0030. I would like to thank the anonymous reviewers for their fruitful and constructive comments.

\section{Other Information}

This article is partly excerpted from Andersson U. (2019) The Visible Vagina: Swedish Legal Narratives about Rape through the Lens of Gender, Place and Vulnerability. In: Andersson U., Edgren M., Karlsson L., Nilsson G. (eds) Rape Narratives in Motion. Palgrave Studies in Crime, Media and Culture. Palgrave Macmillan, Cham. https://doi.org/10.1007/978-3-030-13852-3 5. Copyright @ 2019.

\section{References}

Preparatory works

Proposition 2004/05:45

Proposition 2017/18: 177

SOU 2016:60

SOU 1979:9

\section{Cases}

NJA, Nytt juridiskt arkiv avd I, account of judgments from three instances in a case from the Swedish case report (cited as NJA year, page)

\section{Literature}

Amsterdam, Anthony G. and Bruner, Jerome. 2001. Minding the Law, How Courts Rely on Storytelling, and How Their Stories Change the Way We Understand the Law and Ourselves. Cambridge, MA: Harvard University Press.

Andersson Ulrika. 2019. The Visible Vagina: Swedish Legal Narratives About Rape Through the Lens of Gender, Place and Vulnerability. In Ulrika Andersson, Monika Edgren, Lena Karlsson and Gabriella Nilsson (eds.) Rape Narratives in Motion. Palgrave Studies in Crime, Media and Culture. Palgrave Macmillan, Cham.

Andersson, Ulrika. 2108. Det vardagligas frånvaro. In Ulrika Holgersson and Helena Tolvhed (eds.) Plats för makt. Göteborg: Makadam förlag, 212-226.

Andersson, Ulrika and Edgren, Monika. 2018. Vulnerability, agency and the ambivalence of place in narratives of rape in three high-profile Swedish cases. NORA-Nordic Journal of Feminist and Gender Research 201826 (3): 197-209.

Andersson, Ulrika. 2016. Harmed selves Harming others. A vulnerability approach on the criminal justice system. In Martha Fineman, Ulrika Andersson, and Titti Mattsson (eds.). Privatization, Vulnerability and Social Responsibility: A Comparative Perspective. Abingdon: Routledge, 290300 . 
Andersson, Ulrika. 2004. Hans (ord) eller hennes? En könsteoretisk analys av straffrättsligt skydd mot sexuella övergrepp. Lund: Bokbox.

Andersson, Ulrika. 2001. The unbounded body of the law of rape. In Åsa Gunnarsson, Karin Lundström, Johanna Niemi-Kiesiläinen, and Kevat Nousiainen (eds.). Responsible Selves: Women in the Nordic legal culture. Oxford: Ashgate, 331-351.

Asp, Petter. 2008. Grader av kränkning - våldtäkt eller sexuellt tvång?. Juridisk tidskrift 2008/09 (1): 75-65.

Bell, David and Valentine, Gill (eds.). 1995. Mapping desire: geographies of sexualities. London: Routledge.

Bergenheim, Åsa. 2005. Brottet, offret och förövaren: Vetenskapens och det svenska rättsväsendets syn på sexuella övergrepp mot kvinnor och barn 1850-2000. Stockholm: Carlsson.

Bitsch, Anne and Klemetsen, Marit E. 2017. The legal grading of sexual citizenship: sentencing practices in Norwegian rape cases. Gender, Place \& Culture 24 (2): 174-188. doi: 10.1080/0966369X.2017.1298572

Bonner-Thompson Carl and Hopkins Peter. 2017. Geographies of the Body. New York: Oxford University Press. DOI:10.1093/obo/9780199874002-0157.

Boyle, Karen. 2018. What's in a name? Theorizing the Inter-relationships of gender and violence. Feminist Theory 0 (0): 1-18. https://doi.org/10.1177/1464700118754957

Bumiller, Kristin. 2008. In an Abusive State. How Neoliberalism Appropriated the Feminist Movement Against Sexual Violence. Durham: Duke University Press.

Braverman, Irus, Blomely, Nicholas, Delaney, David and Kedar, Alexander (eds.). 2014. The Expanding Spaces of Law. A timely legal Geography. Stanford, California: Stanford University Press.

Brooks, Peter. 2002. Narrativity of the Law. Law \& Literature 14 (1): 1-10.

Ceccato, Vania, Li, Guangquan and Haining, Robert. The ecology of outdoor rape: The case of Stockholm, Sweden. European Journal of Criminology 2019, Vol. 16(2) 210-236.

Conley, John M. and O’Barr, William M. 1990. Rules Versus Relations. The Ethnography of Legal Discourse. Chicago: University of Chicago Press.

Cuomo, Dana and Brickell, Katherine. 2019. Feminist legal Geographies. Economy and Space 51(5): 1043-1049.

Edgren, Monika. 2019. Conditional vulnerability: Rape narratives in Swedish courts, 1990-2014. Andersson U., Edgren M., Karlsson L., Nilsson G. (eds.) Rape Narratives in Motion. Palgrave Studies in Crime, Media and Culture. Palgrave Macmillan, Cham.

Edgren, Monika. 2016. Trauma-Ett tveeggat narrativ om våldtäkt. Retfaerd 39 (3): 17-30.

Edwards, Alice. 2010. Everyday rape. International human rights law and violence against women in peacetime. In Clare McGlynn and Vanessa Munro (eds.). Rethinking Rape Law. International and Comparative Perspectives. Abingdon: Routledge, 92-108.

Ehrlich, Susan. 2001. Representing Rape. Language and sexual consent, London: Routledge.

Ekström, Simon. 2001. Last och lust i våldtäktsmål. Stockholm 1946-1950. In I. Lövkrona (ed.). Mord, misshandel och sexuella övergrepp: Historiska och kulturella perspektiv på kön och våld. Lund: Nordic Academic Press, 145-67.

Ewick, Patricia and Silbey, Susan S. 1998. The Common Place of Law. Stories from Everyday Life. Chicago: University of Chicago Press.Estrich, Susan. 1987. Real rape, Cambridge, Mass.: Harvard University Press.

Fatta. 2018. 5 sätt Fatta drev igenom samtyckeslagen. http://fatta.nu/5-satt-fatta-drev-igenomsamtyckeslagen/ (Accessed 2018-08-12).

Fineman, Albertson, Martha. 2008. The Vulnerable Subject: Anchoring Equality in the Human Condition. Yale Journal of Law and Feminism 20 (1): 1-23. 
Fineman, Albertson, Martha. 2010. The vulnerable Subject and the Responsive State. Emory Law Journal 60: 251- 274.

Fineman, Albertson, Martha. 2017. Vulnerability and Inevitable inequality. [2017] Oslo Law Review: 133-149.

Grear Anna. 2010. Redirecting human rights: Facing the challenge of corporate legal humanity. Basingstoke: Palgrave MacMillan.

Javaid, Aliraza. 2018. Out of place: Sexualities, sexual violence, and heteronormativity. Aggression and Violent Behavior 39: 83-86.

Jeffrey, Alex. 2020. Legal Geography II: Bodies and Law. Progress in Human Geography 44(5): 1004-1016.

Johnston, Lynda. 2017. Gender and sexuality III: Precarious places. Progress in Human Geography 20 (10): 1-9.

Johnston, Lynda and Longhurst, Robyn. 2010. Space, Place, and Sex: Geographies of Sexualities. Lanham: Rowman \& Littlefield.

King, Brian W. 2011. Language, sexuality and place: The view from cyberspace. Gender and Language 5 (1): 1-30.

Korling, Fredrik and Zamboni, Mauro (eds.). 2013. Juridisk metodlära. Lund: Studentlitteratur.

McKenzie-Mohr, Suzanne. 2014. Counter-storying rape. Women's efforts toward liberatory meaning making. In Suzanne McKenzie-Mohr and Micehll Lafrance (eds.). Women voicing resistance: Discursive and narrative Explorations. London \& New York: Routledge, 64-83.

McKenzie-Mohr, Suzanne and Lafrance, Michelle. N (eds.). 2014. Women voicing resistance: Discursive and narrative Explorations. London \& New York: Routledge.

Lacey, Nicola. 1997. Unspeakable subjects, impossible rights: Sexuality, integrity and criminal law. Women: A Cultural Review 8 (2): 143-157.

Langellier, Kristin M. and Peterson, Eric E. 2004. Storytelling in Daily Life. Performing Narrative. Philadelphia: Temple University Press.

Leijonhufvud, Madeleine. 2015. Svensk sexualbottslag. En framåtsyftande tillbakablick. Stockholm: Norstedts Juridik.

Longhurst, Robyn. 2001. Bodies. Exploring fluid boundaries, London and New York: Routledge.

McGlynn, Clare. 2008. Rape as 'Torture'? Catharine MacKinnon and Questions of Feminist Strategy. Feminist Legal Studies 16 (1): 71-85. doi: 10.1007/s10691-007-9079-5.

Mardorossian, Carine M. 2014. Framing the Rape Victim: Gender and Agency Reconsidered. New Brunswick: Rutgers University Press.

Marvel, Stu 2016. Response to Tuerkheimer - rape on and off campus the vulnerable subject of rape law: rethinking agency and consent. Emory Law Journal Online 65: 2035- 2049.

Moran, Les and Skeggs, Beverley. 2004. Sexuality and the Politics of Violence and Safety. London and New York: Routledge.

Naffine, Ngaire. 2002. Can Women be Legal Persons?. In Susan James and Stephanie Palmer (eds.). Visible Women: Essays on Feminist Legal Theory and Political Philosophy. Oxford: Hart, 150-173.

Niemi, Johanna. 2010. What We Talk About When We Talk About Buying Sex. Violence Against Women 16 (2): 159-172.

Niemi-Kiesiläinen, Johanna, Honkatukia, Päivi och Ruuskanen, Minna. 2007. Legal Texts as Discourses. In Åsa Gunnarsson, Eva-Maria Svensson and Margaret Davies (eds.) Exploiting the Limits of Law: Swedish Feminism and the Challenge to Pessimism, London \& New York; Routledge, 69-88.

Nilsson, Gabriella. 2019. Narrating the moral geography of rape in Swedish newspapers. In Ulrika Andersson, Monika Edgren, Lena Karlsson and Gabriella Nilsson (eds) Rape Narratives in Motion. Palgrave Studies in Crime, Media and Culture. Palgrave Macmillan, Cham 
Philippopoulos-Mihalopoulos, Andreas. 2018. And For Law: Why Space cannot be understood without Law. In Law, Culture \& the Humanities, 1-20.

Philippopoulos-Mihalopoulos, Andreas. 2015. Spatial Justice: Body, Lawscape, Atmosphere. Abingdon, Oxon: Routledge

Philippopoulos-Mihalopoulos, Andreas, 2010. Spatial justice: Law and the geography of withdraw. In International Journal of Law in Context, 6,3: 201-216.

Serisier, Tanya. 2019. A New Age of Believing Women? Judging Rape Narratives Online. In Ulrika Andersson, Monika Edgren, Lena Karlsson and Gabriella Nilsson (eds) Rape Narratives in Motion. Palgrave Studies in Crime, Media and Culture. Palgrave Macmillan, Cham

Smart, Carol. 1995. Law, Crime and Sexuality: Essays in feminism. London: Sage.

Stringer, Rebecka. 2014. Vulnerability after wounding: Feminism, rape law and The Differend. SubStance 42 (3): 148-168.

Temkin, Jennifer. 2002. Rape and the Legal Process. Oxford: Oxford University Press.

Thompson, Fullilove, Mindy and McSharry, McGrath, Moriah (eds.). 2005. Introduction to the Special Issue on Sexuality and Place. The Journal of Sex Research 42 (1): 1-2.

Tuerkheimer, Deborah, "Sex Without Consent, 123 Yale Law Journal Online 335 , (Dec. 1, 2013) at http://www.yalelawjournal.org/images/pdfs/1222.pdf" (2013). College of Law Faculty Publications. Paper 193.

Tyner, James A. 2011. Space, Place and Violence: Violence and the Embodied Geographies of Race, Sex and Gender. $1^{\text {st }}$ ed. New York: Routledge.

Wegerstad, Linnéa. 2015. Skyddsvärda intressen och straffvärda kränkningar. Ph.D. diss., Lund University.

Wegerstad, Linnéa. 2012. Om erotik och makt och sexualbrottens sexualitet. In Ulrika Andersson, Hege Brækhus, Monica Burman, Anne Hellum, Stine Jørgensen, Eva-Maria Svensson(eds.). På vei. Kjønn og rett i Norden. Göteborg: Makadam, 273-297.

Wendt Höjer, Maria. 2002. Rädslans politik: Våld och sexualitet i den svenska demokratin. Malmö: Liber ekonomi. 